\title{
CFD Modeling of Meat and Bone Meal Combustion in a Rotary Cement Kiln
}

\author{
W. K. Hiromi Ariyaratne, Anjana Malagalage, Morten C. Melaaen, and Lars-André Tokheim
}

\begin{abstract}
This paper presents a three-dimensional computational fluid dynamics (CFD) modeling study carried out for a rotary cement kiln withal multi-channel burner with swirl and high momentum air components. The simulations are performed using the commercial CFD software ANSYS FLUENT, version 13.0, and are carried out for coal as well as for meat and bone meal (MBM) combustion using the eddy-dissipation model for combustion. Steady-state solutions are obtained using the Lagrangian approach for the particle phase and the Eurasian approach for the continuous phase. The turbulence is modeled by the RNG $k-\varepsilon$ model, and gas-phase radiation is modeled by the $P 1$ radiation model. The effect of MBM fuel properties on combustion characteristics such as temperature, fuel devolatilization, volatiles and char burning, in comparison with coal, are presented and discussed. It was found that MBM combustion products temperatureis300K lower than that of coal, and the char burnout of MBM is $83 \%$. This poor burnout is mainly due to bigger MBM particles.
\end{abstract}

Index Terms - CFD, combustion, meat and bone meal, rotary cement kiln.

\section{INTRODUCTION}

Typically, cement clinker production requires 3.3-4.0 $\mathrm{MJ} / \mathrm{kg}$ clinker of thermal energy; depending on the process [1]. The precalciner and the rotary kiln are the main thermal energy consuming units in a cement plant. Coal and other fossil fuels have traditionally been used as fuels in cement kilns. Nevertheless, because of the high energy cost and high environmental impact of the process, many cement companies have turned to energy-rich waste-derived fuels. The range of waste-derived fuels is extremely wide. Many plants meet a considerable part of their energy requirements with waste-derived fuels, for example meat and bone meal (MBM), waste tires, waste oils, solvents, plastics, paper, wood, rubber, sewage and refused derived fuels (RDF) [2]. With respect to the global warming scenario, maximum use of biomass fuels is vital since it gives no net $\mathrm{CO}_{2}$ emissions to the atmosphere. However, some characteristics ofthose fuels can impact the kiln process adversely, and may for example reduceclinker quality, production rate, or kiln refractory life. Therefore, in order to optimize and control the whole kiln process, it is important to understand the impacts of such secondary fuel burning along with the relevancy of their characteristics.

CFD modelingisa good tool to predict the combustion

Manuscript received April 25, 2014; revised July 1, 2014.

The authors are with Telemark University College, Department of Process, Energy and Environmental Technology, Faculty of Technology, Kjølnes Ring 56, Post box 203, N-3901 Porsgrunn, Norway (e-mail: hiromi.ariyaratne@hit.no, morten.c.melaaen@hit.no,Lars.A.Tokheim@hit.no). characteristics inside a rotary cement kiln. An overview of published results from the application of modelingon the cement kiln process ispresented in the following paragraphs.

A partial differential model has been developed for coal/oil flame, and the dynamic response has been studied for different effects, e.g. initial gas temperature, gas velocity and solids flow rate [3]. A steady state mathematical model for different zones inside the kiln has been used to predict the temperature distribution in the solid and gas phases, and also the composition of former phase [4].

A CFD code has been used to predict flow/combustion behavior for axisymmetric flow inside a cement kiln for coal combustion, and temperature, velocity and product concentration profiles have been calculated [5]. Comparison of thek- $\varepsilon$ model and the Reynolds stress model for turbulence in pulverized-coal flame in a non-swirling high velocity cement kiln burner is analyzed and NO emissions have been predicted [6].

Other authors have employed a comprehensive mathematical model for a petroleum coke fired non-swirl burner and have predicted influence of wall temperature, primary air velocity, secondary air temperature, fuel particle size, and refractory thickness on ignition, temperature, $\mathrm{O}_{2}$ and NO concentrations, and heat transfer [7]. In several publications [8]-[12], flow, mixing patterns, flame length predictions as well as bed and gas temperature profiles can be found for coal- combusted cement kilns. The feed bed may be represented as a moving solid region [11].

In order to quantify energy fluxes from the flame to the clinker and the heat loss from the kiln, one may model the coal-fired rotary cement kiln using ax symmetric CFD code (FLOW-3D) in conjunction with a radiation module (RAD-3D) [13]. Flame structure, kiln and clinker temperature distribution and clinker compositions have been predicted, and the effects of oxygen enrichment and dust insufflations on kiln parameters have been investigated by coal combustion simulations with clinker motion and reactions [14].

2D ax symmetric model predictions for a blend of bituminous coal and anthracite combustion in a rotary cement kiln can also be found [15]. Some researchers have developed a 3D steady state model to predict the flow and heat transfer in a rotary lime kiln by coupling three sub-models, namely a hot flow model, bed model and wall model [16].

A parameter study of emissivity's of gas, wall, material, thickness of brickwork, false air and entraining characteristics on heat and material flow has also been carried out [17]. Others have numerically modeled a rotary cement kiln with combined CFD (Cinar ICE which includes 1D clinkerization model) and thermo chemical equilibrium calculations, and incorporation of minor components into the 
clinker has been predicted [18]. The commercial 3D CFD code FLUENT coupled with a 1D heat flux function model has been used to investigate the pulverized-coal combustion behavior in a rotary kiln with a four-channel burner, and the clinker formation has been studied [19].

A $1 D$ reaction engineering model has been developed in order to simulate key processes in the solid bed of the cement kiln [20], [21]. Solid-solid reactions, variation of bed height and melt formation inside the kiln were taken into account. Bed and gas temperature, clinker composition and factors affecting the overall energy consumption have been analyzed and the model has been used to simulate performance of three industrial kilns. Since a 1D model cannot catch the influence of burner design and key operating parameters such as axial:swirl ratio, oxygen enrichment, coal particle size and ash content on flame characteristics, FLUENT has been used to couple models for the bed and freeboard regions [22]. Also, an integrated reaction engineering based mathematical model and a software (RoCKS) has been developed for the whole kiln system by same authors [23].

3D simulations for a multi-air channel coal burner has been carried out using the CFX software, and the effects of air flow ratios and fuel mean diameter on temperature distribution and flame features have been presented [24].Others have developed a multi-fuel CFD code coupled with mineral reactions (MI-CFD) and presented simulated results for e.g. temperature and $\mathrm{CO}$ and $\mathrm{NO}$ concentrations for long wet-kilns fired with coal, natural gas and whole tires [25].

3D CFD modeling of a full scale rotary cement kiln with a multi-channel coal burner can be found in another paper, in which ANSYS FLUENT has been used withal zone-wise heat flux model to study the effect of swirl angle on combustion characteristics [26]. An implementation and validation of the calcinations reaction mechanism of limestone in a CFD code can also be found [27].

Process simulations of cement kilns can also be found [28, 29], and such simulations have been used to investigate for example the air and energy demands for MBM and sewage sludge combustion in rotary cement kilns [28]. A comprehensive review and evaluation of combustion flame models can be found in other references [30]-[32].

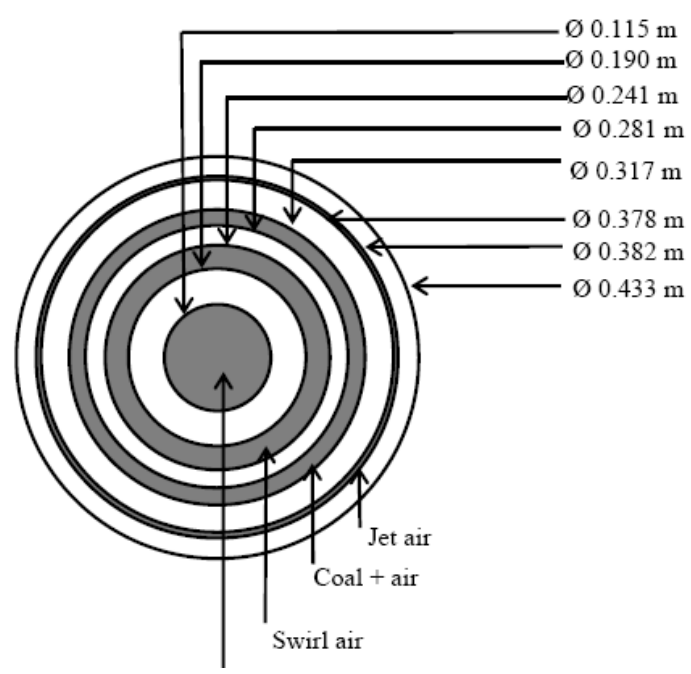

Fig. 1. Dimensions of the real (left) and simplified kiln burner (right).

The review given above shows that there are quite a few publications available on rotary kiln modeling, and many different aspects are covered. However, despite the increased utilization of waste-derived fuels and the impact this may have on flame properties and kiln performance, very little information on CFD modeling of combustion of waste-derived fuels is found in the literature.

In the present study, the commercial CFD software ANSYS FLUENT, version 13.0, was used for modeling and simulation of the combustion process inside a rotary cement kiln. Steady state three-dimensional simulations were carried out. Process parameters; kiln and burner dimensions were taken from a full-scale cement plant in Norway which produces around 3400 tons of clinker per day. Coal was used as a reference fuel, and MBM, which is $100 \%$ biogenic,was selected as the waste-derived fuel. The effects of MBM fuel properties on combustion characteristics such as temperature, fuel devolatilization, volatiles burning and char burning are presented and discussed. The effect of gravity is also concerned and discussed. Since the main focus is on the primary burner combustion process, the solid charge inside the kiln, the clinker reactions and the kiln rotation are not considered.

\section{GEOMETRY AND GRID GENERATION}

A three dimensional $63 \mathrm{~m}$ kiln was created in Gambit 2.4.6. Even though, the real kiln is $68 \mathrm{~m}$ long, the system for the modeling work is defined from burner tip onwards along the kiln, since the details are important only from the burner end onwards.i.e. the $5 \mathrm{~m}$ of axial distance backward from burner tip was not calculated, however, the secondary air inlet boundary conditions of the real kiln was taken as boundary conditions for the secondary air inlet in the simplified system. The real rotary kiln burner was somewhat modified to facilitate modeling (Fig. 1). The 16 swirl air inlets and 20 jet air inlets were converted to annulus sections; however care was taken to usea flow area that would conserve not only mass but also momentum, i.e. the total cross sectional area of each inlet is similar to each of those in real system. Liquid hazardous waste and waste oiling lets were discarded since these are not always used. The solid fuel inlet was moved into the centre. However, in the present study, the waste derived 
fuel is fed through the coal annulus, not through inner circle indicated in the figure, in order to rule out the effect of feeding position (which will be studied separately).The secondary air is fed through the annular space between the burner and the kiln inner surface $(\varnothing 0.433 \mathrm{~m}-\varnothing 3.920 \mathrm{~m})$. The kiln and the burner are taken as horizontal.

The geometry and the mesh were generated in Gambit, version 2.4.6. The mesh is of the Cooper type and consists ofhexahedral elements. The total number of cells in the mesh is 335,907.To optimize convergence and computational time, the grid is finer at the burner area, but coarser at the secondary air inlet. Gradual increments of cell sizes are used along the length of the kiln.

\section{FUEL AND GAS PROPERTIES}

Key fuel and gas properties used in the model are presented here. The particle size distributions are shown in Fig. 2 and ultimate analysis, proximate analysis, heating value, dry particle density [33], [34], water-liquid fraction anddevolatilization kinetic parameters [35], [36] for the two fuels are presented in Table I. ANSYS FLUENT default model parameters are used for char combustion of both fuels [37]. In plastic coals, such as bituminous coals, formation and escape of gas-filled bubbles result the swelling of the particle [38]. The swelling coefficient is defined as 1.4 for coal and 1 for MBM in the present study. In ANSYS FLUENT, the particles are introduced as a number of uniform surface injections.

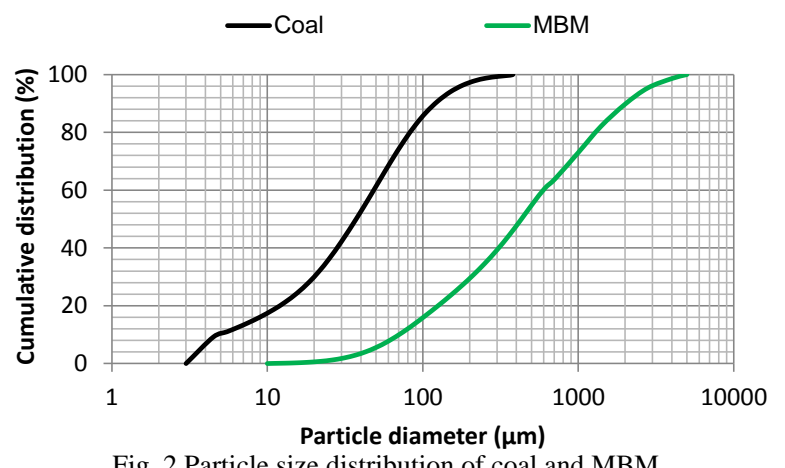

Fig. 2.Particle size distribution of coal and MBM.

TABLE I: PROPERTIES OF FUELS (AS RECEIVED BASIS, UNLESS SPECIFIED)

\begin{tabular}{lll}
\hline \hline Property & Coal & MBM \\
\hline $\mathrm{C}(\mathrm{wt} \%)$ & 72.9 & 47.1 \\
$\mathrm{H}(\mathrm{wt} \%)$ & 3.9 & 6.9 \\
$\mathrm{O}(\mathrm{wt} \%)$ & 5.6 & 4.5 \\
$\mathrm{~S}(\mathrm{wt} \%)$ & 1.4 & 0.5 \\
$\mathrm{~N}(\mathrm{wt} \%)$ & 1.7 & 9.7 \\
Volatiles (wt\%) & 23.0 & 60.9 \\
Fixed carbon $(\mathrm{wt} \%)$ & 62.4 & 8.0 \\
Ash (wt\%) & 13.6 & 27.1 \\
Moisture (wt\%) & 1.0 & 4.0 \\
HHV (MJ/kg) & 29.06 & 19.99 \\
Dry particle density $\left(\mathrm{kgm}^{-3}\right)$ & 1287 & 1354 \\
Water-liquid fraction $(\mathrm{vol} \%)$ & 0.0131 & 0.056 \\
Activation energy for devolatilization $(\mathrm{J} / \mathrm{mol})$ & $7.400 \mathrm{e} 4$ & $1.745 \mathrm{e} 5$ \\
Frequency factor for devolatilization $\left(\mathrm{s}^{-1}\right)$ & $3.82 \mathrm{e} 5$ & $8.33 \mathrm{e} 11$ \\
Smallest particle diameter $(\mu \mathrm{m})$ & 3.75 & 10.5 \\
Largest particle diameter $(\mu \mathrm{m})$ & 373 & 4500 \\
Mass-weighted average particle diameter $(\mu \mathrm{m})$ & 53.8 & 793.9 \\
\hline \hline
\end{tabular}

Specific heat capacities of different gas components are defined as temperature polynomials [39]. The composition-dependent specific heat capacity is calculated for the gas mixture. The density of the gas mixture is treated according to the incompressible ideal gas law.

\section{BOUNDARY CONDITIONS}

The air inlets are treated as velocity inlets. The velocity is calculated from known mass flow rates from the real kiln system. Fuel conveying air mass flow rates are fuel type dependent. The secondary air mass flow rate is calculated in order to get 2 vol\% of $\mathrm{O}_{2}$ in the exhaust gas after complete combustion, hence that flow rate will also be different for different fuels (Table II).

The swirl number $S$ specific to the current burner, collected from the plant, is 0.261 . Then the tangential velocity $w$ at the swirl inlet is determined from (1).

$$
w=S u
$$

$u$ is the axial velocity $\mathrm{c}$ the inlet and is calculated from the mass flow rate at that inlet. The local cylindrical coordinate system is used to define the velocity components at swirl inlet. The outlet of the system is treated as a pressure-outlet. All the walls are treated as adiabatic and no-slip walls.

\begin{tabular}{lllll}
\multicolumn{5}{l}{ TABLE II: MOMENTUM AND THERMAL CONDITIONS AT AIR INLETS AND } \\
OUTLET
\end{tabular}

\section{MODEL DESCRIPTION}

\section{A. Gas Phase}

The steady state continuity equation can be written as in (2). The source $S_{m}$ is resulted from combustion of particles. The velocity components in $x, y, z$ directions are given by (3), which include normal and shear forces, gravitational force (buoyancy effect) and the source term arising from interaction between gas and solid.

$$
\begin{gathered}
\nabla \cdot(\rho \vec{v})=S_{m} \\
\nabla \cdot(\rho \vec{v} \vec{v})=-\nabla P+\nabla \cdot(\overline{\bar{\tau}})+\rho \vec{g}+\vec{F}
\end{gathered}
$$

where, $\overline{\bar{\tau}}$ is stress tensor given by (4). $\mu_{\text {eff }}$ models the effect of molecular and turbulence viscosity.

$$
\overline{\bar{\tau}}=\mu_{e f f}\left[\left(\nabla \vec{v}+\nabla \vec{v}^{T}\right)-\frac{2}{3} \nabla \cdot \vec{v} I\right] .
$$

Since the flow also has a moderate swirl $(S<0.5)$, the RNG $k$ - $\varepsilon$ model is used for turbulence. The equations for $k$ and $\varepsilon$ are as follows.

$$
\begin{gathered}
\frac{\partial}{\partial x_{i}}\left(\rho k u_{i}\right)=\frac{\partial}{\partial x_{i}}\left[\alpha_{k} \mu_{e f f} \frac{\partial k}{\partial x_{i}}\right]+G_{k}+G_{b}-\rho \varepsilon \\
\frac{\partial}{\partial x_{i}}\left(\rho \varepsilon u_{i}\right)=\frac{\partial}{\partial x_{i}}\left[\alpha_{\varepsilon} \mu_{e f f} \frac{\partial \varepsilon}{\partial x_{i}}\right]+C_{1 \varepsilon} \frac{\varepsilon}{k} G_{k}-C_{2 \varepsilon}^{*} \rho \frac{\varepsilon^{2}}{k}
\end{gathered}
$$

$G_{k}$ represents the generation of turbulence kinetic energy due to the mean velocity gradients, and $G_{b}$ is the generation of turbulence kinetic energy due to buoyancy. One of the 
important features of the RNG model relative to the standard model is the ability to account for the effect of swirl in the mean flow on turbulence. For that, the turbulent viscosity is appropriately modified.

The energy transfer happens due to different temperatures of flow streams and chemical reactions. The energy equation can be written in vector notation as follows.

$$
\nabla \cdot(\vec{v}(\rho E+P))=\nabla \cdot\left(k_{e f f} \nabla T-\sum_{i} h_{i} \vec{J}_{i}+\left(\overline{\bar{\tau}}_{e f f} \cdot \vec{v}\right)\right)+S_{h}(7)
$$

The first three terms on the right hand side represent energy transfer due to conduction, species diffusion and viscous dissipation, respectively. $S_{h}$ includes the heat of chemical reaction and radiation. In (7), $E=h-\frac{P}{\rho}+\frac{v^{2}}{2}$.

Owing to the high operating temperature in the rotary kiln, radiation is the predominant mode of heat transfer. This can be divided into gaseous non-luminous emission $\left(\mathrm{CO}_{2}, \mathrm{H}_{2} \mathrm{O}\right.$, $\mathrm{CO}$, etc) and luminous-particulate emission (char, ash, soot). However, for fuel-lean systems, the soot radiation might be insignificant [31]. In the present modeling, gas phase gray radiation is modeled using the $P_{1}$ model available in ANSYS FLUENT. Particulate effects from char and ash on radiation were not included. The radiation flux is determined by solving an equation for incident radiation. This radiation flux can be directly substituted into the energy equation to account for heat sources or sinks due to radiation.

$$
\begin{gathered}
-\nabla \cdot q_{r}=\nabla \Gamma \nabla \mathrm{G}=a G-4 a n^{2} \sigma T^{4} \\
\text { Here }, \Gamma=\frac{1}{\left(3\left(a+\sigma_{s}\right)-C \sigma_{s}\right)} .
\end{gathered}
$$

The weighted-sum-of-gray-gases model (WSGGM) in ansys fluent calculates the composition-dependent absorption coefficient for $\mathrm{CO}_{2}$ and $\mathrm{H}_{2} \mathrm{O}$ mixtures. Other gaseous species $\left(\mathrm{CO}, \mathrm{SO}_{2}, \mathrm{NO}\right)$ are often of secondary importance because of low concentration [31].

The species transport equation is solved in order to get results for combustion species. The species conservation equation is solved for $N-1$ species where $N$ is the total number of fluid phase chemical species present in the system.

$$
\nabla \cdot\left(\rho \vec{v} Y_{i}\right)=-\nabla \cdot \vec{J}_{i}+R_{i}+S_{i}
$$

Here $\vec{J}_{i}$ is the mass diffusion flux in turbulent flows and it is computed as in (10). $S_{i}$ is the rate of creation by addition from the dispersed phase. $R_{i}$ is the net rate of production of species $i$ by chemical reaction and is defined by the eddy-dissipation model [40] since the bulk (gas) phase reactions (combustion of volatiles) are rapid and combustion is said to be mixing-controlled. The $R_{i, r}$ (for reaction $r$ ) is given by the smaller of the two expressions of (11) and (12).

$$
\begin{gathered}
\vec{J}_{i}=-\left[\rho D_{i, m}+\frac{\mu_{t}}{S c_{t}}\right] \nabla Y_{i}-D_{T, i} \frac{\nabla T}{T} \\
R_{i, r}=v_{i, r}^{\prime} M_{w, i} A \rho \frac{\varepsilon}{k} \min _{\boldsymbol{R}}\left[\frac{Y_{\boldsymbol{R}}}{v_{\boldsymbol{R}, r}^{\prime} M_{w, \boldsymbol{R}}}\right] \\
R_{i, r}=v_{i, r}^{\prime} M_{w, i} A B \rho \frac{\varepsilon}{k} \frac{\sum_{p} Y_{p}}{\sum_{j}^{N} v_{j, r}^{\prime} M_{w, j}}
\end{gathered}
$$

Thevolatiles burning is treated as two step global reactions; as below.

$$
\begin{gathered}
\text { volatiles }+v_{\mathrm{O}_{2}} \mathrm{O}_{2} \rightarrow v_{\mathrm{CO}} \mathrm{CO}+v_{\mathrm{H}_{20}} \mathrm{H}_{2} \mathrm{O}+v_{\mathrm{SO}_{2}} \mathrm{SO}_{2}+v_{\mathrm{N}_{2}} \mathrm{~N}_{2} \\
\mathrm{CO}+0.5 \mathrm{O}_{2} \rightarrow \mathrm{CO}_{2}
\end{gathered}
$$

\section{B. Particle Phase}

The Lagrangian discrete phase model is selected for the present study. The trajectory and heat/mass transfer calculations are based on the force balance (15) and velocity definition (16) of the particle and also on the heat/mass transfer of the particle due to interaction with continuous phase. Turbulence model impacts from turbulent eddies produced by particles are not considered.

The force balance on the particle is calculated by (15). Stepwise integration over discrete time steps yields the velocity of the particle at each point along the trajectory, with the trajectory itself predicted by (16).

$$
\begin{gathered}
\frac{d \vec{u}_{p}}{d t}=F_{D}\left(\vec{v}-\vec{u}_{p}\right)+\frac{\vec{g}\left(\rho_{p}-\rho\right)}{\rho_{p}} \\
\frac{d \vec{x}}{d t}=\vec{u}_{p}
\end{gathered}
$$

$F_{D}\left(\vec{v}-\vec{u}_{p}\right)$ is the drag force per unit particle mass.

$$
F_{D}=\frac{18 \mu}{\rho_{p} d_{p}^{2}} \frac{C_{d} R e}{24}
$$

Coal and MBM particles are considered as smooth and spherical in shape; therefore, the spherical drag law is used to define $C_{d}$.

$$
C_{d}=a_{1}+\frac{a_{2}}{R e}+\frac{a_{3}}{R e^{2}}
$$

$a_{1}, a_{2}$ and $a_{3}$ are according to Morsi and Alexandar [41].

In the present study, the stochastic tracking approach (random walk model) is used to catch the turbulence effect of fluid phase on particle dispersions. This approach solves the trajectory equations using the instantaneous fluid velocity $(\bar{u}+\dot{u})$ instead of the mean velocity of the fluid $(\bar{u})$. Ten in dependent tracking are used for each particle stream.

The combustion process of fuel particles includes heating, fuel moisture evaporation and heating, devolatilization, homogeneous volatiles burning, heterogeneous char-burning and residual ash heating.

The devolatilization law is applied to the particle from $T_{p} \geq T_{\text {vap }}$ until $m_{p}>\left(1-f_{v, 0}\right)\left(1-f_{w, 0}\right) m_{p, 0}$. The single kinetic rate devolatilization model, which assumes that the rate of devolatilization is first-order, dependent on the amount of volatiles remaining in the particle, is used in the present study.

$$
-\frac{d m_{p}}{d t}=k_{1}\left[m_{p}-\left(1-f_{v, 0}\right)\left(1-f_{w, 0}\right) m_{p, 0}\right]
$$

The kinetic rate $k$ is defined by the Arrhenius equation; $k_{1}=A_{1} e^{-\left(\frac{E_{1}}{R T_{p}}\right)}$

The particle diameter changes due to a swelling effect during devolatilization, and is defined by the following equation.

$$
\frac{d_{p}}{d_{p, 0}}=1+\left(C_{s w}-1\right) \frac{\left(1-f_{w, 0}\right) m_{p, 0}-m_{p}}{f_{v, 0}\left(1-f_{w, 0}\right) m_{p, 0}}
$$


Heat transfer to the particle during the devolatilization process includes only the contribution from convection, as radiation heat transfer to the particles is not concerned in our study.

$$
m_{p} c_{p} \frac{d T_{p}}{d t}=h_{1} A_{p}\left(T_{\infty}-T_{p}\right)
$$

The surface combustion law is applied to the particle from $m_{p}<\left(1-f_{v, 0}\right)\left(1-f_{w, 0}\right) m_{p, 0} \quad$ until $\quad m_{p}>\left(1-f_{v, 0}-\right.$ $\left.f_{\text {comb }}\right)\left(1-f_{w, 0}\right) m_{p, 0}$. The kinetic/diffusion limited rate model, which assumes that the char combustion rate is determined either by kinetics or by a diffusion rate, is used[37]. The particle size is assumed to remain constant in this model.

$$
\frac{d m_{p}}{d t}=-A_{p} p_{o x} \frac{D_{0} \boldsymbol{R}_{\mathbf{1}}}{D_{0}+\boldsymbol{R}_{\mathbf{1}}}
$$

where, $D_{0}=C_{1} \frac{\left[\left(T_{p}+T_{\infty}\right) / 2\right]^{0.75}}{d_{p}}$ and $\boldsymbol{R}_{\mathbf{1}}=C_{2} e^{-\left(\frac{E_{1}}{R T_{p}}\right)}$.

The particle heat balance during char combustion includes convection and heat released by reaction.

$$
m_{p} c_{p} \frac{d T_{p}}{d t}=h_{1} A_{p}\left(T_{\infty}-T_{p}\right)-f_{h} \frac{d m_{p}}{d t} H_{\text {reac }}
$$

Aportion of the released energy is absorbed by the particle, and the rest is released to the gas phase. Assuming that the char burnout product is $\mathrm{CO}_{2}, 30 \%$ of the reaction heat is absorbed by the particle [42].

\section{SOlution StRATEGY AND CONVERGENCE CRITERION}

Ansys fluent, which is based on the finite volume approach, is used for solving the set of governing equations. Since the current cases can be considered incompressible flow cases, the pressure-based solver is selected. A segregated algorithm called "SIMPLE" is selected for the pressure-velocity coupling. Moreover, first order upwind spatial discretization scheme was used for the convection term of each governing equation. The under-relaxation factors were carefully adjusted to ensure solution convergence. For the level of accuracy, the limited residual values for convergence are $10^{-3}$ for all the equations except for the energy and radiation equations in which $10^{-6}$ was used.

\section{Simulation CASES}

The MBM mass flow rate is defined in order to have the same energy input to the kiln as the coal reference case i.e. 63.8 MW. The fuel temperature and velocity are similar to that of the air stream which conveys the fuel into the kiln. Two cases are simulated; in the first case, the total energy required by the rotary kiln is supplied by pure coal $(2.26 \mathrm{~kg} / \mathrm{s})$; then, in the second case,the energy is supplied by MBM (3.45 $\mathrm{kg} / \mathrm{s}$ ). Table II gives other relevant information.

\section{RESULTS AND DISCUSSION}

Below, selected simulation results are plotted and discussed. Here, "coal" refers to the coal combustion case and "MBM" refers to the MBM combustion case.

As seen in Fig. 3, the maximum mass-weighted temperature for coal is around $300 \mathrm{~K}$ higher than for MBM.
The energy-specific stoichiometric air demand for coal and MBM are $0.338 \mathrm{~kg} / \mathrm{MJ}$ and $0.411 \mathrm{~kg} / \mathrm{MJ}$, respectively, resulting from the ultimate analysis and heating value of the fuel. The higher molar H/C ratio of MBM gives a lower air requirement. Nevertheless, the lower net calorific value and the lower oxygen content of MBM give a higher air requirement. The net energy-specific air demand is a result of all these effects, and in this case the positive effect of higher molar $\mathrm{H} / \mathrm{C}$ ratio of $\mathrm{MBM}$ is being outweighed by the other two factors. This higher energy-specific air flow rate and also higher moisture content of MBM will give a higher exhaust gas flow rate and hence reduce the temperature of the MBM combustion products. The higher ash and moisture content in MBM also contribute to reduced temperature, since the ash and evaporated water vapour should be heated up to the equilibrium temperature. It was also found that the combusted char percentage at the kiln end is $99.5 \%$ for coal and $83.2 \%$ for MBM. This poor char burnout behavior of MBM compared to coal lowers the temperature even more for MBM. However, since the volatiles fraction in MBM is high, the $17 \%$ unburnt char corresponds to only $1 \%$ of the total energy flow into the kiln, so it does not have a huge impact on the temperature, probably only in the range of $10{ }^{\circ} \mathrm{C}$. The reasons for the poor char burnout will be discussed below. However, it should be noted that in a real cement kiln, the profile will be quite different due to interaction from the solid raw materials and the non-uniform heat loss through the shell. Thus, one should expect a decreasing temperature after the maximum point [19]. The fact that burning MBM in higher rates reduces the flame temperature and hence heat transfer in the kiln has been verified by a full-scale experiment and published in another paper [43].

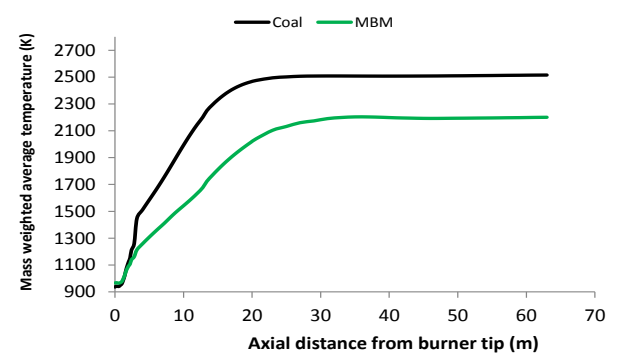

Fig. 3. Mass-weighted average temperature in the gas phase along the kiln.

Having a high volatiles content compared to coal (Table I), MBM shows intense devolatilization nearby the burner, and it also extends a longer into the kiln (Fig. 4). The MBM volatiles mass fraction variation plots also confirm this observation. However, both fuels start devolatilization around $1 \mathrm{~m}$ from the burner tip (Fig. 5). The different devolatilization kinetics of the two fuels may also be a reason for different volatiles concentration profiles. This will be further investigated in another study.

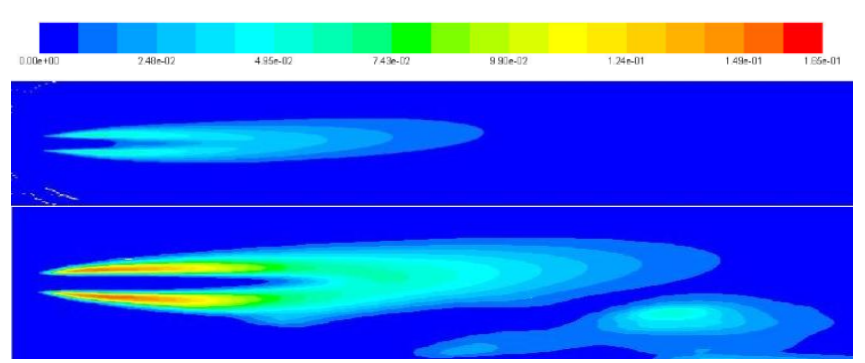

Fig. 4. Contours of volatiles mass fraction foraxial region from burner tipto $27 \mathrm{~m}$ for coal (top) and MBM (bottom) 


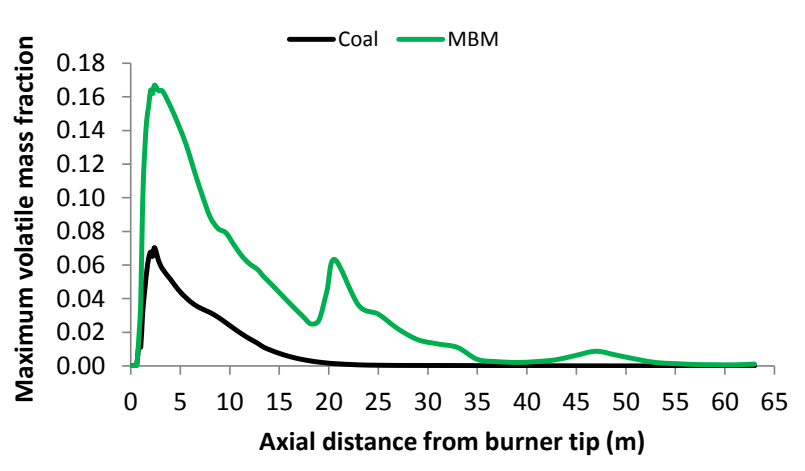

Fig. 5. Maximum volatiles mass fractionsat different cross sections along the kiln.

Some local high volatiles regions can be observed in the lower part of the kiln by $21 \mathrm{~m}$ distance from the burner tip in MBM case (Fig. 4). These local high-volatiles spots along the kiln (in addition to main devolatilization in the beginning) can also be observed in Fig. 5; e.g. around $21 \mathrm{~m}$ and $47 \mathrm{~m}$ distance from the burner tip. Fig. 6 and Fig. 7 can be used to explain the reason for these local peak areas in the lower part of the kiln.

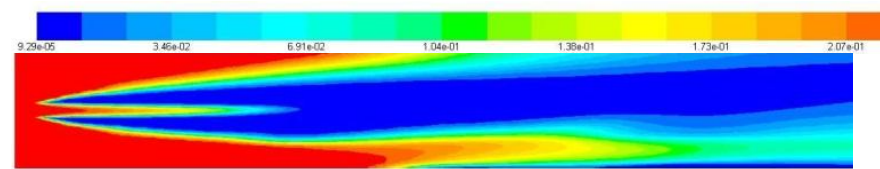

Fig. 6. Contours of $\mathrm{O}_{2}$ mass fraction for MBM (from burner tip to $27 \mathrm{~m}$ ).

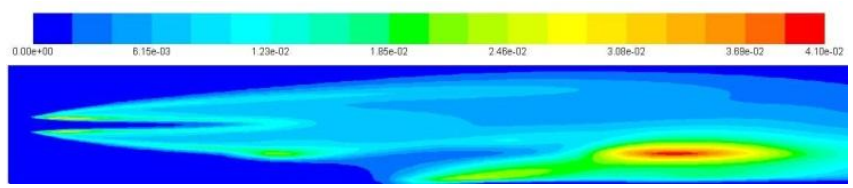

Fig. 7. Contours of CO mass fraction for MBM (from burner tip to 27m).

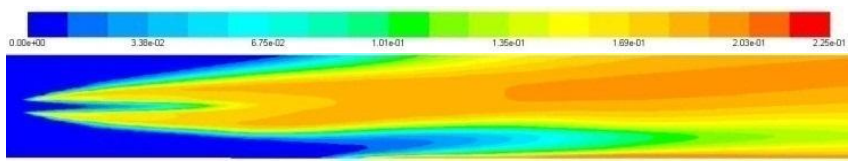

Fig. 8. Contours of $\mathrm{CO}_{2}$ mass fraction for MBM (from burner tip to 27m).

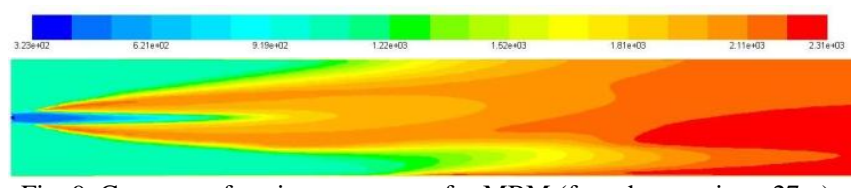

Fig. 9. Contours of static temperature for MBM (from burner tip to $27 \mathrm{~m}$ ).

The particle sizes of MBM are quite large compared to coal (the largest MBM particle diameteris 12 times bigger than the largest coal particle; and the mass-weighted mean particle diameter is 15 times bigger) and these bigger particles pass gradually off-axis and decline due to the gravity effect. Smaller particles tend to spread over the whole kiln cross section and devolatilize quite symmetrically over the kiln cross section (Fig. 4) since they are much less affected by gravity due to their low mass. This effect is similar for coal too, but a much more significant effect can be seen for MBM,since the particle diameters of MBM spreads through a wide range. Therefore, the devolatilization of bigger particles continuesat the lower part of the kiln producing more volatiles (Fig. 4). There is $\mathrm{O}_{2}$ available in that area (Fig. 6), so these volatiles are oxidized to $\mathrm{CO}$ (Fig. 7). However, the $\mathrm{CO}_{2}$ concentration is low (Fig. 8), indicating that oxidation of $\mathrm{CO}$ to produce $\mathrm{CO}_{2}$ is quite slow, due to poor mixing. This poor oxidation of $\mathrm{CO}$ can also be identified from temperature contours, i.e. reduced temperature in that area (Fig. 9).

As defined in the model, char combustion mainly depends on particle temperature, initial fuel particle diameter and oxygen availability. Fixed carbon content of the fuel is also an important parameter.

Fig. 10 andand Fig. 11 show the char mass fraction of ten random particles of same size $(20 \mu \mathrm{m})$ for coal and MBM, respectively. $20 \mu \mathrm{m}$ particles were selected, because thatsize can represent smaller particles, whose effect is analyzed here. The randomness of 10 particles in each of Fig. 10, 11 and 13 is only due to different particle history, i.e. stochastic tracking of particles. Generally, in both cases, the char mass fraction starts to increase first, when volatiles are released (Fig. 10 and Fig. 11). Then the char mass fraction starts to decrease in MBM due to char burning, and finally it ends up with a zero value, once all char is completely burnt (Fig. 11). However, in the coal case, it can be observed that the char mass fraction is quite constant over a considerable path length during char combustion, implying that the coal char burning process is quite slow in some steps, even for smaller particle diameters. This slow burning can also be observed for MBM particles which are greater than $855 \mu \mathrm{m}$. Coal char burning path is longer $(18 \mathrm{~m})$ than that of MBM $(10 \mathrm{~m})$. This is due to high fixed carbon content of coal compared to MBM.

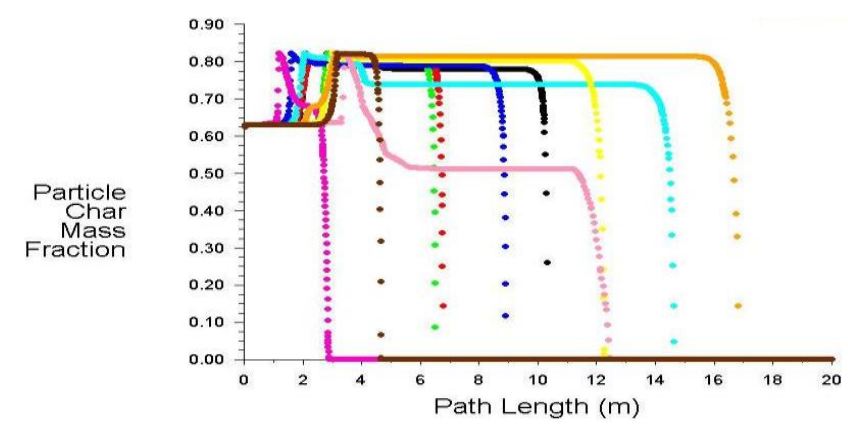

Fig. 10. Coal char mass fraction variation of ten random $20 \mu \mathrm{m}$ particles.

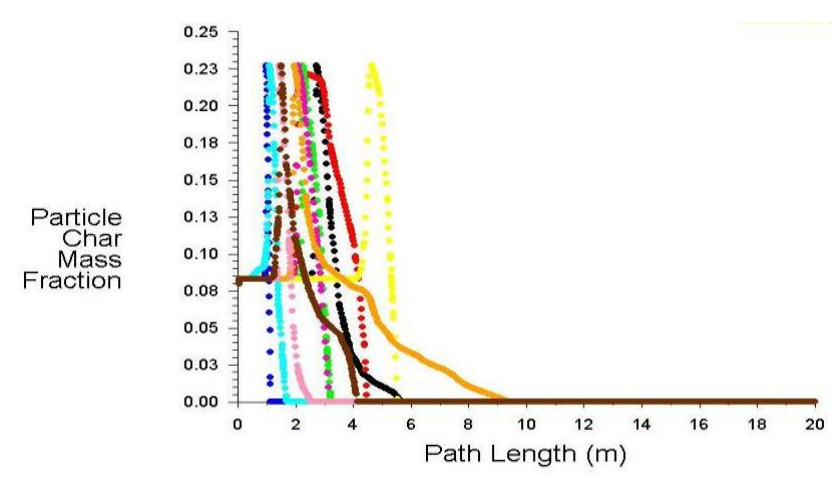

Fig. 11. MBM char mass fraction variation of ten random $20 \mu \mathrm{m}$ particles.

As seen in Fig. 12, the oxygen mass fraction profile for coal shows that the oxygen level is gradually decreasing till around $40 \mathrm{~m}$ of kiln length and is then quite constant at around $2 \mathrm{wt} \%$. MBM also shows same trend, however around 2-4 wt $\%$ is higher than that of coal all the way, and it is slowly decreasing even to the end of the kiln, indicating that some fuel oxidation still goes on in the MBM case. Generally, it can be concluded that in both cases, enough oxygen was available for the combustion process, and well in accordance with the calculated air demand. 


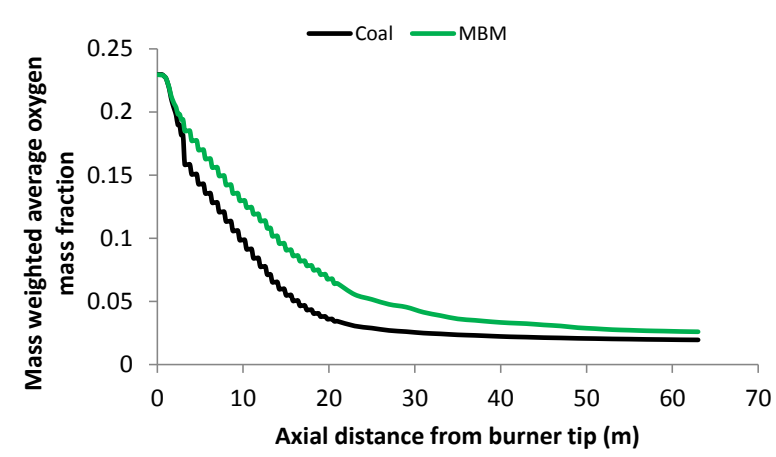

Fig. 12. Mass-weighted average oxygen mass fraction along the kiln.

Fig. 13 shows that the coal char is completely burnt before it exits the kiln, even for the largest particles of coal. It was found that the particle temperatures of coal are high (2000-2500 K), even for larger particles. However, the situation for larger particles of MBM is quite different.

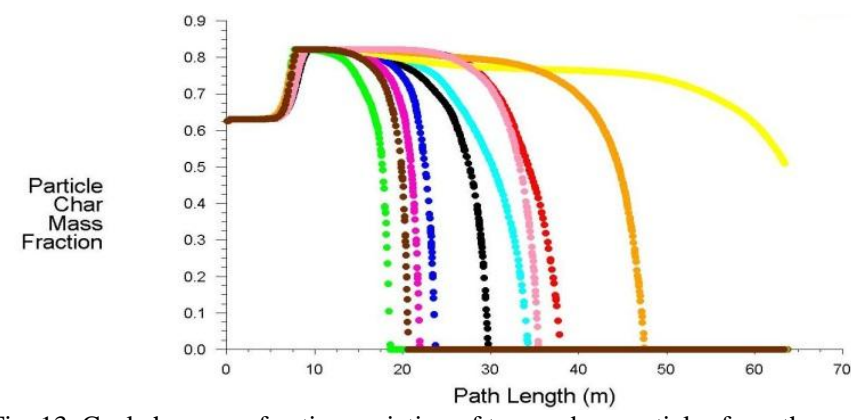

Fig. 13. Coal char mass fraction variation of ten random particles from the largest diameter particles $(372.5 \mu \mathrm{m})$.

According to Fig. 14, the MBM particles with the largest size $(4500 \mu \mathrm{m})$ have neitherbeen subjected to devolatilizationnor to char burning. The second largest particles $(3400 \mu \mathrm{m})$ have also not been subjected to char burning, but devolatilization is ongoing towards the end of the kiln. In general, the smaller the particle, the earlier the devolatilization is completed. So it appears that char burning is getting slower when increasing the particle diameter, and this can be explained by the particle temperature (Fig. 15). Hence, for the bigger particles, the temperature is too low for char combustion to occur.

As seen in Fig. 16, coal char is burnt significantly faster than MBM char. The maximum mass-weighted char burning rate can be observed 11-12m away from the burner tip for both fuels. Gradual decrements of mass-weighted char burning rates can be observed for both fuels after some distance (Fig. 16), however, intense local char burning areas were observed along the kiln length for MBM.

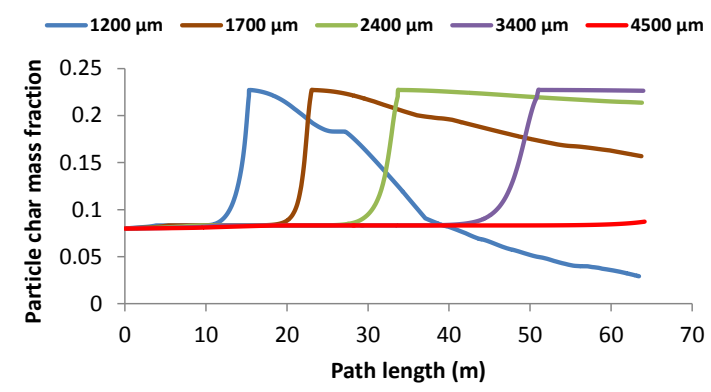

Fig. 14. Char mass fraction variation of a random particle selected from the larger diameter streams of MBM.

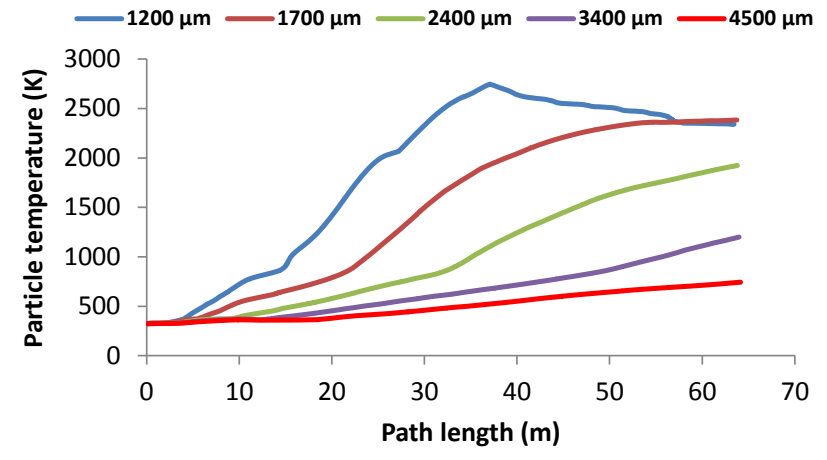

Fig. 15. Particle temperature variation of a random particle selected from the larger diameter streams of MBM.

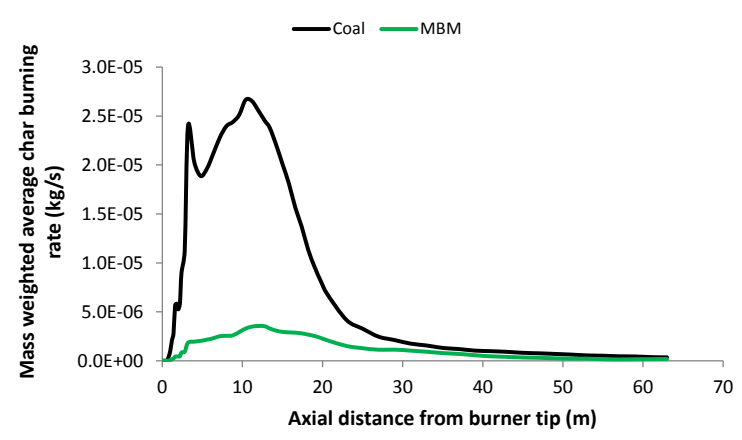

Fig. 16. Mass-weighted average char burning rate along the kiln.

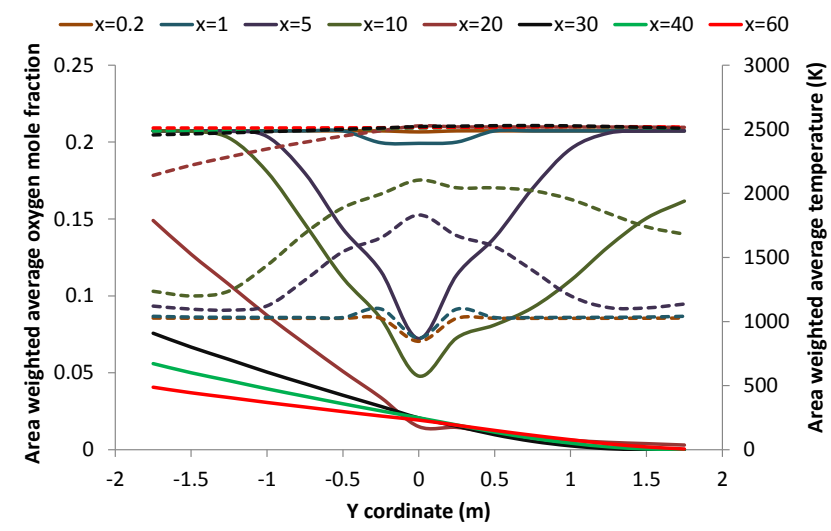

Fig. 17. Area-weighted average oxygen mole fraction and temperature variation in the gas phase in $\mathrm{x}$ and $\mathrm{Y}$ direction for coal(colours correspond to certain $\mathrm{x}$ position, solid lines correspond to oxygen concentration and dash lines correspond to temperature).

Area-weighted average oxygen mole fractions and area-weighted average temperature variations in radial direction $(Y)$ in different locations along the kiln length $(x)$ are presented for coal (Fig. 17). The temperature at the centre of the kiln nearby the burner tip is around $850 \mathrm{~K}$ (Fig. 17). This is higher than the primary air temperature, which might be due to backward heat transfer from the combustion zone, basically caused by radiation. The oxygen mole fraction at the centre drops drastically in the combustion zone (e.g. at $x=5$ and $x=10$ ) due to consumption, and the temperature increases consequently due to intense combustion. According to Fig. 17, asymmetric oxygen and temperature profiles in $Y$ direction can be observed after $x=5$ till $x=30$. A higher oxygen mole fraction can be observed in the lower part of the kiln compared to the upper part, and inverse for the temperature. A similar effect is observed for MBM combustion, however asymmetric profile starts after $x=10$. In both cases, uniform temperature profiles along $\pm Y$ direction 
can be seen after $x=30$. The higher oxygen mole fraction in the lower part of the kiln can be due to; 1) hot combustion products tend to ascend due to the buoyancy effect and will then displace cold oxygen in the upper part of the kiln; 2) bigger fuel particles tend to decline due to the gravity effect, causing poor burning and hence less consumption of oxygen and reduced temperature. The higher oxygen mole fractions of MBM (at $x=20$ and $x=30$ ) at the lower part of the kiln compared to coal verifies the second effect, because MBM particles are significantly larger.

\section{CONCLUSION}

Meat and bone meal (MBM) combustion and coal combustion in a rotary cement kiln were simulated and the results were compared. The equilibrium temperature of the MBM combustion products is around $300 \mathrm{~K}$ lower than those from coal combustion. The lower temperature is mainly due to thehigher air demand, higher ash and moisture content andpoor char burnout (83\%) of MBM.

Even if enough oxygen is availabile for combustion, local volatiles-concentrated areas along the kiln could be observed in the lower part of the kiln for MBM. Most importantly, it was found that the largest MBM particles $(4500 \mu \mathrm{m})$ are not subjected to either devolatilization or char burning and devolatilization and char burning is getting slower when increasing the particle diameter of larger particles. The particle temperature is significantly lower for the larger MBM particles, explaining the lower char burnout of larger particles.

In general, for both fuels, a higher oxygen mole fraction could be observed in the lower part of the kiln. This can be due to buoyancy effects on the hot gas and gravity effects on the particles. The impact of the latter is significant in MBM combustion.

\section{NOMENCLATURE}

$\begin{array}{cl}A & \text { empirical constant, } 4.0 \\ A_{1} & \text { Arrhenius type pre-exponential factor, } \mathrm{s}^{-1} \\ A_{p} & \text { droplet surface area, } \mathrm{m}^{2} \\ a & \text { absorption coefficient, } \mathrm{m}^{-1} \\ a_{1}, a_{2}, a_{3} & \text { constants } \\ B & \text { empirical constant, } 0.5 \\ C & \text { linear-anisotropic phase function coefficient } \\ C_{1} & \text { mass diffusion limited rate constant, } \mathrm{s} \mathrm{K}^{-0.75} \\ C_{2} & \text { kinetics-limited rate pre-exponential } \\ & \text { factor,sm }{ }^{-1} \\ \mathrm{C}_{1 \varepsilon} & \text { model constant, } 1.42 \\ C_{2 \varepsilon}^{*} & \text { model constant } \\ C_{d} & \text { drag coefficient } \\ C_{s w} & \text { swelling coefficient } \\ c_{p} & \text { heat capacity at constant pressure, } \mathrm{J} / \mathrm{kg} \mathrm{K} \\ D_{i, m} & \text { mass diffusion coefficient for species } i \text { in the } \\ D_{T, i} & \text { mixture, } \mathrm{m}^{2} / \mathrm{s} \\ D_{0} & \text { thermal (Soret) diffusion coefficient, } \mathrm{kg} / \mathrm{m} \mathrm{s} \\ d_{p} & \text { diffusion rate coefficient, sm }{ }^{-1} \\ d_{p, 0} & \text { current particle diameter, } \mathrm{m} \\ E & \text { particle diameter at the start of devolatilization, } \\ E_{1} & \text { total energy, } \mathrm{J} / \mathrm{kg} \\ & \text { activation energy, } \mathrm{J} / \mathrm{kmol} \\ & \end{array}$

\begin{tabular}{|c|c|}
\hline$\vec{F}$ & external body force vector, $\mathrm{N} / \mathrm{m}^{3}$ \\
\hline$F_{D}$ & drag force, $\mathrm{s}^{-1}$ \\
\hline$f_{c o m b}$ & combustible fraction \\
\hline$f_{h}$ & fraction of the heat absorbed by the particle \\
\hline$f_{v, 0}$ & $\begin{array}{l}\text { mass fraction of volatiles initially present in the } \\
\text { particle }\end{array}$ \\
\hline$f_{w, 0}$ & $\begin{array}{l}\text { mass fraction of the evaporating/boiling } \\
\text { material }\end{array}$ \\
\hline$G$ & incident radiation, $\mathrm{W} / \mathrm{m}^{2}$ \\
\hline$G_{b}$ & $\begin{array}{l}\text { generation of turbulence kinetic energy due to } \\
\text { buoyancy, } \mathrm{J} / \mathrm{m}^{3} \mathrm{~s}\end{array}$ \\
\hline$G_{k}$ & $\begin{array}{l}\text { generation of turbulence kinetic energy due to } \\
\text { the mean velocity gradients, } \mathrm{J} / \mathrm{m}^{3} \mathrm{~s}\end{array}$ \\
\hline$\vec{g}$ & gravitational acceleration, $\mathrm{m} / \mathrm{s}^{2}$ \\
\hline$H_{\text {reac }}$ & heat released by the surface reaction, $\mathrm{J} / \mathrm{kg}$ \\
\hline$h$ & enthalpy, $\mathrm{J} / \mathrm{kg}$ \\
\hline$h_{i}$ & enthalpy of species $i, \mathrm{~J} / \mathrm{kg}$ \\
\hline$h_{1}$ & convective heat transfer coefficient, $\mathrm{W} / \mathrm{m}^{2} \mathrm{~K}$ \\
\hline$I$ & unit tensor \\
\hline$\vec{J}_{i}$ & diffusion flux of speciesi, $\mathrm{kg} / \mathrm{m}^{2} \mathrm{~s}$ \\
\hline$k$ & turbulent kinetic energy per unit mass, $\mathrm{J} / \mathrm{kg}$ \\
\hline$k_{1}, \boldsymbol{R}_{\mathbf{1}}$ & kinetic rate, $\mathrm{s}^{-1}$ and $\mathrm{sm}^{-1}$ \\
\hline$k_{e f f}$ & effective thermal conductivity, W/m K \\
\hline$M_{w, i}$ & molecular weight of species $i, \mathrm{~kg} / \mathrm{kmol}$ \\
\hline$m_{p}$ & current mass of the particle, $\mathrm{kg}$ \\
\hline$m_{p, 0}$ & initial mass of the particle, $\mathrm{kg}$ \\
\hline$n$ & refractive index \\
\hline$P$ & static pressure, $\mathrm{Pa}$ \\
\hline$p_{o x}$ & $\begin{array}{l}\text { partial pressure of oxidant species in the gas } \\
\text { surrounding the combusting particle, } \mathrm{Pa}\end{array}$ \\
\hline$q_{r}$ & radiation heat flux, $\mathrm{W} / \mathrm{m}^{3}$ \\
\hline$R$ & gas-law constant, $8.31447 \times 10^{3} \mathrm{~J} / \mathrm{kmolK}$ \\
\hline$R e$ & relative Reynolds number \\
\hline$R_{i, r}$ & $\begin{array}{l}\text { net rate of production of species } i \text { due to } \\
\text { reaction } r, \mathrm{~kg} / \mathrm{m}^{3} \mathrm{~s}\end{array}$ \\
\hline$R_{i}$ & $\begin{array}{l}\text { net rate of production of species } i \text { by chemical } \\
\text { reaction, } \mathrm{kg} / \mathrm{m}^{3} \mathrm{~s}\end{array}$ \\
\hline$S$ & swirl number \\
\hline$S_{h}$ & $\begin{array}{l}\text { heat of chemical reaction and any other } \\
\text { volumetric heat source, } \mathrm{W} / \mathrm{m}^{3}\end{array}$ \\
\hline$S_{i}$ & $\begin{array}{l}\text { rate of creation of specie } i \text { by addition from the } \\
\text { dispersed phase, } \mathrm{kg} / \mathrm{m}^{3} \mathrm{~s}\end{array}$ \\
\hline$S_{m}$ & $\begin{array}{l}\text { mass added to the continuous phase from the } \\
\text { dispersed second phase, } \mathrm{kg} / \mathrm{m}^{3} \mathrm{~s}\end{array}$ \\
\hline$S c_{t}$ & turbulent Schmidt number \\
\hline$T$ & temperature, $K$ \\
\hline$T_{b p}$ & boiling point, $K$ \\
\hline$T_{p}$ & particle temperature, $K$ \\
\hline$T_{\text {vap }}$ & vaporization/devolatilizationtemperature, $K$ \\
\hline$T_{\infty}$ & local temperature of the continuous phase, $K$ \\
\hline$t$ & time, $\mathrm{s}$ \\
\hline$u$ & axial velocity, $\mathrm{m} / \mathrm{s}$ \\
\hline$u_{i}$ & velocity magnitude in $i^{\text {th }}$ direction, $\mathrm{m} / \mathrm{s}$ \\
\hline$\vec{u}_{p}$ & particle velocity vector, $\mathrm{m} / \mathrm{s}$ \\
\hline $\bar{u}$ & mean fluid phase velocity, $\mathrm{m} / \mathrm{s}$ \\
\hline$\dot{u}$ & $\begin{array}{l}\text { instantaneous value of the fluctuating gas flow } \\
\text { velocity, } \mathrm{m} / \mathrm{s}\end{array}$ \\
\hline$v$ & velocity, m/s \\
\hline$\vec{v}$ & overall velocity vector, $\mathrm{m} / \mathrm{s}$ \\
\hline
\end{tabular}


$w \quad$ tangential velocity, $\mathrm{m} / \mathrm{s}$

$x_{i} \quad$ distance in $i^{\text {th }}$ direction, $\mathrm{m}$

$\vec{x} \quad$ overall distance vector, $\mathrm{m}$

$Y_{i} \quad$ mass fraction of species $i$

$Y_{p} \quad$ mass fraction of a particular product species $p$

$Y_{\boldsymbol{R}} \quad$ mass fraction of a particular reactant $\boldsymbol{R}$

\section{Greek letters}

$\begin{array}{cl}\alpha_{k} & \text { inverse effective Prandtl number for } k \\ \alpha_{\varepsilon} & \text { inverse effective Prandtl number for } \varepsilon \\ \varepsilon & \text { turbulent dissipation rate, } \mathrm{m}^{2} / \mathrm{s}^{3} \\ \mu & \text { molecular viscosity of the fluid, Pa s } \\ \mu_{e f f} & \text { effective dynamic viscosity, Pa s } \\ \mu_{t} & \text { turbulent viscosity, Pa s } \\ v_{i, r}^{\prime} & \text { stoichiometric coefficients for reactant } i \text { in } \\ & \text { reaction } r \\ v_{j, r}^{\prime} & \text { stoichiometric coefficients for product } j \text { in } \\ & \text { reaction } r \\ \rho & \text { density of continuous phase, } \mathrm{kg} / \mathrm{m}^{3} \\ \rho_{p} & \text { density of the particle, } \mathrm{kg} / \mathrm{m}^{3} \\ \sigma & \text { Stefan-Boltzmann constant, } 5.67 \times 10^{-8} \mathrm{~W} / \mathrm{m}^{2} \\ & \mathrm{~K}^{4} \\ \sigma_{s} & \text { scattering coefficient, } \mathrm{m}^{-1} \\ \overline{\bar{\tau}} & \text { stress tensor }, \text { Pa } \\ \overline{\bar{\tau}}_{e f f} & \text { effective stress tensor, Pa } \\ \Gamma & \text { parameter in radiation }\end{array}$

\section{REFERENCES}

[1] Z. Demján, The Possible Impact of CO2 Trading on Competitiveness of Cement Industry, Slovak Cement \& Lime Association, 2005.

[2] A. Rahman, M. G. Rasul, M. M. K. Khan, and S. Sharma, "Impact of Alternative Fuels on the Cement Manufacturing Plant Performance: An Overview," Procedia Engineering, vol. 56, pp. 393-400, 2013.

[3] H. A. Spang, "A dynamic model of a cement kiln," Automatica, vol. 8, pp. 309-323, 1972

[4] H. K. Guruz, and N. Bac, "Mathematical modelling of rotary cement kilns by the zone method," The Canadian Journal of Chemical Engineering, vol. 59, no. 4, pp. 540-548, 1981.

[5] T. Avgeropoulos, J. P. Glekas, and C. Papadopoulos, "Numerical simulation of the combustion aerodynamics inside a rotary cement kiln," Energy Efficiency in Process Technology, Pilavachi PA: Springer Netherlands, 1993, pp. 767-778.

[6] F. C. Lockwood and B. Shen, "Performance predictions of pulverised-coal flames of power station furnace and cement kiln types," in Proc. Symposium (International) on Combustion, vol. 25, no. 1, pp. 503-509, 1994.

[7] F. C. Lockwood, B. Shen, and T. Lowes, "Numerical study of petroleum coke fired cement kiln flames," presented at the third International Conference on Combustion Technologies for a Clean Environment, Lisbon, Portugal July 3-6, 1995.

[8] E. Kolyfetis, and N. C. Markatos, "Aerodynamics and coal- Flame modelling in the burning zone of cement rotary kilns, part $1, " \mathrm{ZKG}$ international, vol. 49, no. 1, pp. 24-35, 1996.

[9] E. Kolyfetis and N. C. Markatos, "Aerodynamics and coal- Flame modelling in the burning zone of cement rotary kilns, part 2," ZKG international, vol. 49, no. 6, pp. 326-334, 1996.

[10] N. C. Markatos, "Mathematical modelling of single- and two-phase flow problems in the process industries," Revue de l'institut franais $d u$ petrole, vol. 48, no. 6, pp. 631-662, 1998.

[11] K. C. Karki, S. V. Patankar, and J. Grant, "Simulation of Fluid Flow, Combustion, and Heat Transfer in a Coal-Fired Cement Kiln," presented at the Combustion, Fire, and Computational Modeling of Industrial Combustion Systems, 2000

[12] S. V. Patankar, "Computational modeling of flow and heat transfer in industrial applications," International Journal of Heat and Fluid Flow, vol. 23 , no. 3, pp. 222-231, 2002.
[13] E. Mastorakos et al., "CFD predictions for cement kilns including flame modelling, heat transfer and clinker chemistry," Applied Mathematical Modelling, vol. 23, no. 1, pp. 55-76, 1999.

[14] O. Marin, O. Charon, J. Dugue, S. Dukhan, and W. E. I. Zhou, "Simulating the impact of oxygen enrichment in a cement rotary kiln using advanced computational methods," Combustion Science and Technology, vol. 164, no. 1, pp. 193-207, 2001.

[15] L. Y. Hou, W. B. Fu, and Y. J. Zhang, "A theoretical analysis on combustion intensification for blended coal in rotary cement kiln," Fuel, vol. 80, no. 11, pp. 1645-1650, 2001.

[16] M. Georgallis, P. Nowak, M. Salcudean, and I. S. Gartshore, "Mathematical modelling of lime kilns," presented at the International Chemical Recovery Conference, 2001.

[17] G. Locher, "Mathematical models for the cement clinker burning process-Part 3: Rotary kiln," ZKG international, vol. 55, no. 2, pp. $68-80,2002$

[18] T. Ginsberg, D. Liebig, M. Modigell, K. Hack, and S. Yousif, "Simulation of a cement plant using thermochemical and flow simulation tools," presented at the European Symposium on Computer Aided Process Engineering- 15, 2005.

[19] S. Wang, J. Lu, W. Li, J. Li, and Z. Hu, "Modelling of pulverised coal combustion in cement rotary kiln," Energy \& Fuels, vol. 20, pp. 2350-2356, 2006.

[20] K. S. Mujumdar, A. Arora, and V. V. Ranade, "Modeling of Rotary Cement Kilns: Applications to Reduction in Energy Consumption," Industrial \& Engineering Chemistry Research, vol. 45, no. 7, pp 2315-2330, 2006.

[21] K. S. Mujumdar and V. V. Ranade, "Simulation of Rotary Cement Kilns Using a One-Dimensional Model," Chemical Engineering Research and Design, vol. 84, no. 3, pp. 165-177, 2006.

[22] K. S. Mujumdar and V. V. Ranade, "CFD modeling of rotary cement kilns," Asia-Pacific Journal of Chemical Engineering, vol. 3, no. 2, pp. 106-118, 2008

[23] K. S. Mujumdar, K. V. Ganesh, S. B. Kulkarni, and V. V. Ranade, "Rotary Cement Kiln Simulator (RoCKS): Integrated modeling of pre-heater, calciner, kiln and clinker cooler," Chemical Engineering Science, vol. 62, no. 9, pp. 2590-2607, 2007.

[24] A.-C. Ma, J.-M. Zhou, J.-P. Ou, and W.-X. Li, "CFD prediction of physical field for multi-air channel pulverized coal burner in rotary kiln," Journal of Central South University of Technology, vol. 13, no. 1, pp. $75-79,2006$.

[25] S. Suhail, T. Abbas, and F. C. Lockwood, "Advanced Computational Tools for Cement Plants." Cement Industry Technical Conference Record, 2008 IEEE, 18-22 May 2008, 2008.

[26] T. P. Bhad, S. Sarkar, A. Kaushik, and S. V. Herwadkar, "CFD modelling of a cement kiln with multi channel burner for optimization of flame profile," presented at the seventh International Conference on CFD in the Minerals and Process Industries, Australia, pp. 9-11, 2009

[27] H. Mikulčić et al., "Numerical modelling of calcination reaction mechanism for cement production," Chemical Engineering Science, vol. 69 , no. 1 , pp. 607-615, 2012

[28] M. Modigell, D. Liebig, and S. Munstermann, "Calculation of the clinker burning process using thermochemical process simulation," ZKG international, vol. 55, no. 7, pp. 38-46, 2002.

[29] U. Kääntee, R. Zevenhoven, R. Backman, and M. Hupa, "Cement manufacturing using alternative fuels and the advantages of process modelling," Fuel Processing Technology, vol. 85, no. 4, pp. 293-301, 2004.

[30] S. L. Douglas, "Pulverized coal diffusion flames: A perspective through modeling," Presented at the Symposium (International) on Combustion, 1981

[31] S. L. Douglas, "Modeling of coal-combustion processes," Progress in Energy and Combustion Science, vol. 10, no. 2, pp. 229-267, 1984.

[32] G. Nathan and B. B. Dally, "Challenges and progress in the modelling of heat transfer and NOx emissions from rotary kiln flames involving unsteady flows," Presented at the Third International Conference on CFD in the Minerals and Process Industries, 2003.

[33] O. P. Mahajan and P. L. Walker, "Porosity of coals and coal products," in Analytical methods for coal and coal products 1, USA: Acedamic Press.Inc, 1978, pp. 125-162.

[34] R. A. Garcia, K. A. Rosentrater, and R. A. Flores, "Characteristics of North American meat and bone meal relevant to the development of non-feed applications," Applied Engineering in Agriculture, vol. 22, no. 5, pp. 729-736, 2006.

[35] S. Badzioch and P. G. W. Hawksley, "Kinetics of Thermal Decomposition of Pulverized Coal Particles," Industrial \& Engineering Chemistry Process Design and Development, vol. 9, no. 4, pp. 521-530, 1970. 
[36] G. Skodras et al., "A kinetic study on the devolatilisation of animal derived byproducts," Fuel Processing Technology, vol. 88, pp. 787-794, 2007.

[37] Fluent, "Discrete Phase," in ANSYS FLUENT Theory Guide, 13.0 ed, USA: Ansys Inc, 2010, pp. 367-454.

[38] S. C. Saxena, "Devolatilization and combustion characteristics of coal particles," Progress in Energy and Combustion Science, vol. 16, no. 1, pp. 55-94, 1990.

[39] A. A. F. Peters and R. Weber, "Mathematical modeling of a $2.25 \mathrm{MWt}$ swirling natural gas flame. Part 1: eddy break-up concept for turbulent combustion; probability density function approach for nitric oxide formation," Combustion Science and Technology, vol. 110, pp. 67-101, 1995.

[40] B. F. Magnussen and B. H. Hjertager, "On mathematical modeling of turbulent combustion with special emphasis on soot formation and combustion," Symposium (International) on Combustion, vol. 16, no. 1, pp. 719-729, 1977.

[41] S. A. Morsi and A. J. Alexander, "An investigation of particle trajectories in two-phase flow systems," J Fluid Mech, vol. 55, no. 2, pp. 193-208, 1972.

[42] R. K. Boyd, and J. H. Kent, "Three-dimensional furnace computer modelling," Symposium (International) on Combustion, vol. 21, no. 1, pp. 265-274, 1988.

[43] W. K. H. Ariyaratne, M. C. Melaaen, K. Eine, and L. A. Tokheim, "Meat and bone meal as a renewable energy source in cement kilns: Investigation of optimum feeding rate," Presented at the International Conference on Renewable Energies and Power Quality, Las Palmas de Gran Canaria (Spain), 13-15 April, 2010.

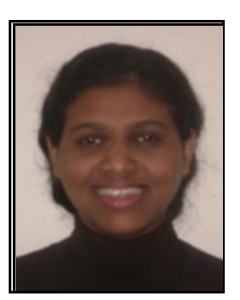

W. K. Hiromi Ariyaratne has one MSc degree in process technology (Telemark University College (TUC), Porsgrunn, Norway, 2009) and another MSc degree in chemical and process engineering (University of Moratuwa (UOM), Moratuwa, Sri Lanka, 2007) and a BSc degree in chemical and process engineering (UOM, 2004).

She is a PhD student at TUC since 2009, where her topic is related to alternative fuel combustion in cement kilns. She has worked on research projects as a research fellow in Sevanagala Sugar Industries (Pvt) Ltd, Sri Lanka and Research and Development Institute, Sri Lanka (2006-2007). She has work experience as a chemical and process engineer in Hammer International (Pvt) Ltd, Sri Lanka (2006) and Linea Intimo (Pvt) Ltd, Sri Lanka (2003). She has also worked at the Department of Chemical and Process Engineering at UOM as Teaching Assistant (2005).

Mrs. Ariyaratne's research interests are alternative fuel combustion in cement clinker production, modeling and simulation, fluid dynamics, heat and mass transfer and cleaner production and waste management techniques.

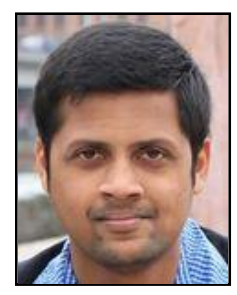

Anjana Malagalage has a BSc degree in chemical and process engineering (University of Moratuwa (UoM), Moratuwa, Sri Lanka, 2010)

$\mathrm{He}$ is an MSc student in process technology at Telemark University College (TUC), Norway since 2012. He has worked at the Department of Chemical and Process Engineering at UoM as a lecturer (probationary) (2010-2012). He has also worked as a summer student at TUC on a research project carried out with StatOil (2013).

Mr. Anjana's research interests are modeling and simulation, fluid mechanics and heat and mass transfer.

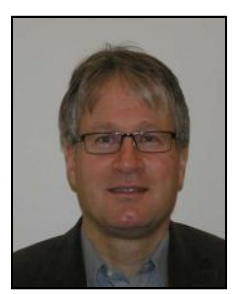

Morten C. Melaaen received his MSc degree in mechanical engineering in 1986 and his $\mathrm{PhD}$ in 1990, both from Norwegian University of Science and Technology (NTNU), Trondheim, Norway.

$\mathrm{He}$ is a professor in process technology at Telemark University College, Porsgrunn, Norway. He is also the dean of Faculty of Technology, Telemark University College and has a part time position at the local research institute Tel-Tek. Earlier, he has worked as a research engineer in Division of Applied Thermodynamics, SINTEF, Norway and as an associate professor at NTNU. He has worked on research projects as a senior research scientist in Norsk Hydro Research Centre Porsgrunn, Norway. He started to work as a professor at Telemark University College in 1994 and became the head of Department, Department of Process, Energy and Environmental Technology in 2002.

Prof. Melaaen's research interests are $\mathrm{CO}_{2}$ capture, modeling and simulation, fluid mechanics and heat and mass transfer. Prof. Melaaen has more than 110 scientific papers published in the above mentioned related fields in international journals and conferences.

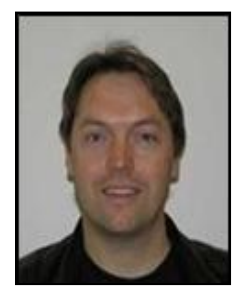

Lars-André Tokheim has a $\mathrm{PhD}$ degree in combustion (Telemark University College (TUC), Porsgrunn, Norway, 1999), an MSc degree in industrial environmental technology (TUC, 1994) and a BSc degree in chemistry (TUC, 1992).

$\mathrm{He}$ is an associate professor at TUC since 2006, where he teaches gas purification and heat \& mass transfer, supervises MSc and $\mathrm{PhD}$ students, and coordinates master study programmes in process technology and energy \& environmental technology as well as a $\mathrm{PhD}$ study programme in process, energy and automation engineering. He has industrial experience from Norcem/Heidelberg Cement since 1994: as a research scholar (1994-1998), as a process engineer in the production department (1998-2001), and as the head of Department for Process Development and Environment (2001-2006).

Prof. Tokheim's main research interests include use of alternative fuels in cement clinker production, calciner technology and gas pollution reduction, in particular $\mathrm{CO}_{2}$ capture and $\mathrm{NO}_{\mathrm{x}}$ reduction. 